University of California, Hastings College of the Law

UC Hastings Scholarship Repository

Faculty Scholarship

2013

Dispute System Design: A Comparative Study of India, Israel and California

Sheila Purcell 


\title{
DISPUTE SYSTEM DESIGN: A COMPARATIVE STUDY OF INDIA, ISRAEL AND CALIFORNIA
}

\author{
Janet Martinez,* Sheila Purcell, ${ }^{* *}$ Hagit Shaked-Gvili, ${ }^{* * *}$ and \\ Mohan Mehta****
}

\section{INTRODUCTION}

Alternative dispute resolution ("ADR") is practiced around the world with myriad approaches, though not without common ground. In an increasingly interconnected world, the sharing of this knowledge and experience has become a natural and even necessary step in the evolution of ADR. ${ }^{1}$ Professor Frank Sander, of Harvard Law School, spoke at the Pound Conference in 1976 and posed the notion of the multi-door courthouse, a concept that led to the development of ADR process options in courts throughout the country. ${ }^{2}$

The deliberate design of one or more processes for handling a stream of similar disputes has come to be known as "dispute system design." 3 Court programs that offer more than just trials, such as mediation or summary jury trials, are one example. This Article

\footnotetext{
* Senior Lecturer in Law and Director of the Gould Negotiation and Mediation Program at Stanford Law School.

** Clinical Professor of Law and Director of the Center for Negotiation and Dispute Resolution at the University of California, Hastings College of the Law.

*** Directed the pilot ADR program at the Tel Aviv Judicial Court, and now provides professional neutral services in Tel Aviv.

**** Justice of the Delhi High Court and Principal Secretary (Law and Justice) with the Government of NCT of Delhi. Ms. Shaked-Gvili and Justice Mehta were Weinstein International Fellows at JAMS, and Visiting Researchers at the Gould Program at Stanford Law School, 2008-11.

1 In the interest of facilitating an international exchange and ongoing network, JAMS founded the Weinstein International Fellowship Program in 2008 to sponsor ADR practitioners from around the world to study dispute resolution processes with scholars and practitioners in the United States. See Weinsterin International Fellowship, JAMS ADR, http://www.jamsadr. com/weinstein-fellowship/ (last visited Jan. 12, 2012).

2 Frank Sander, Address at the National Conference on the Causes of Popular Dissatisfaction with the Administration of Justice: Perspectives on Justice in the Future (Apr. 7-9, 1976).

3 Early leading authors on dispute system design are CATHY A. Costantino \& Christina Sickles Merchant, Designing Conflict Management Systems: A Guide to Creatino Productive and Healthy Organizations (1995); William Ury, Jeanne M. Brett \& Ste. phen B. Goldberg, Getting Disputes Resolved: Designing Systems to Cut the Costs of Conflict (1988). More recent literature on design theory and practice is found in the published volumes from the Ohio State University and Harvard symposia: 14 Harv. Negot. L. Rev. (Winter 2009); Symposium, The Future of ADR: Incorporating Dispute Resolution Into Society, 24 Ohio St. J. on Disp. Resol. (2008).
} 
compares the experience of three diverse court systems at different stages of ADR program development. The three court systems analyzed are courts in Delhi, India; Tel Aviv, Israel; and San Mateo County, California. The first section briefly describes the origins of each court-annexed mediation program. The second section sets out a framework for analysis and then compares the three systems according to these analytic elements. This Article concludes with some observations on cross-cutting themes and trends for the future.

\section{Overview of Three Court Mediation Programs}

\section{A. Delhi Mediation Center}

With a population of over 1.2 billion people, India is the most populated democracy in the world. The federal constitutional republic consists of a multi-ethnic society where more than 400 languages are spoken. Despite various autonomous arbitral bodies and provisions for arbitration and conciliation for particular categories of cases (such as labor and family), litigation in India continues to rise. Currently, about thirty million cases are pending in different courts in India. ${ }^{4}$ With the present rate of disposal, it would likely take over 300 years to clear the backlog. Litigation reflects increased legislation, commercial activities of state entities, and awareness of citizens' rights, and thus, an increased demand for the means to resolve such disputes.

Since independence, several governmental committees have advocated for a reduction in court debts, including judicial education to enhance the capacity of judges in order to improve the quality of their output. Various arbitration and conciliation provisions have been adopted but not fully implemented. The Legal Services Authority Act of 1987 established the lok adalats, or "people's courts,"s throughout the country, which helped settle or otherwise

\footnotetext{
4 Neeta Lal, Huge Case Backlog Clogs India's Courts, Asia Times Online (Jun. 28, 2008), http://www.atimes.com/atimes/South_Asia/JF28Dr02.html.

5 Lok adalats have been established throughout India. Each is presided over by a retired judicial officer along with a lawyer and social worker. Cases, usually money disputes, are conciliated to reach a settlement. There is no fee, and no appeal. Agreements are binding and can be executed through a legal process. See Marc Galanter \& Jayanth K. Krishnan, "Bread for the Poor": Access to Justice and the Rights of the Needy in India, 55 HASTINGs L.J. 789 (2004); Gregg
} 
dispose of a significant number of cases; however, litigation has continued to increase.

In 2002, the Ahmedabad Bar Association developed a program for dispute settlement by mediation, which was followed by the setup of mediation programs in Mumbai, Chennai, and Madurai under Section 89 of the Civil Procedure Code. ${ }^{6}$ The Supreme Court approved the Civil Procedure Alternative Dispute Resolution and Mediation Rules in 2003. The former Chief Justice of India, R.C. Lahoti, studied all existing efforts and decided to constitute a Mediation and Conciliation Project Committee (MCPC) consisting of judges of the Supreme Court and High Court and Senior Advocates, to encourage mediation as the most viable ADR option to address cases in the district courts. The MCPC was constituted in April 9, 2005, with the objective of providing centralized direction and support for mediation.

A pilot project was started in the Delhi district courts under the auspices of the National Legal Services Authority (NALSA), with trainers provided free of charge by the Institute for the Study and Development of Legal Services (ISDLS) of California. A judicial mediation system commenced in September of 2005 in the Tis Hazari District Court, with six trained judicial officers assigned one day per week, to deal with mediated cases. The disputants' feedback was positive, since the system was not only free of cost and expeditious, but also friendly and devoid of the intimidation associated with the formal legal process.

The initial success led to the establishment of the Delhi Mediation Center, which currently has four working centers at District Courts in Tis Hazari, Karkardooma, Rohini, and Dworka, with a fifth due to open in Saket. Each center is manned by a senior judicial officer of the rank of Additional District Judge, who administers the center and examines and assigns the cases for mediation to the mediators. ${ }^{7}$ The summary statistics as of December 2012 are as follows: ${ }^{8}$

F. Relyea, Mediation and Case Management: Legal Reforms Promise to Transform Legal Landscape in India, 9 Disp. Resol. MAG. 13 (2003).

6 Section 89 stipulates that arbitration, conciliation, judicial settlement, lok adalat and mediation are optional modes of ADR.

7 For current information, see DeLHI Mediation CENTRE, delhimediationcentre.gov.in (last visited Jan. 12, 2012).

8 General Statistics Report, Delhi Mediation Centre, delhimediationcentre.gov.in (last visited Jan. 12, 2012). 


\begin{tabular}{|l|l|}
\hline Total number of cases referred & $71,115 / 71,916$ \\
\hline Number of cases fit for mediation & 11,117 \\
\hline Number of cases settled & $40,761(69 \%) / 42,954$ \\
\hline Average time spent per case & 75 minutes \\
\hline
\end{tabular}

\section{B. Israel Judicial Court in Tel Aviv}

The Israeli court system is a highly valued public service with an enormous annual caseload. ${ }^{9}$ A comparative study of judiciary cases in seventeen countries determined that Israel ranked highest in the number of cases submitted per population $(600,000$ cases per year for a population of $7,645,000)$, sixth place in the number of judges per population (660 residing judges), and first place in judicial caseload. ${ }^{10}$

In order to cope with the heavy caseload and keep the public faith in the judicial system, the Israeli court system has undergone extensive reform over the past decade. It has transformed itself from a traditionally adversarial institution with individual judges working independently of one another, to a more active system of interconnected departments. The direct result of the modifications has been a significant relief of the overburdened judicial system and substantial improvement of the system's efficiency.

Based on British colonial law, the Israeli judicial system had been using the same traditional methods for nearly five decades. The transformation of the system was undertaken through two major changes. ${ }^{11}$ The first change involved the revision of existing case-management methods. The second was the introduction of ADR into the judiciary. Each of the policy shifts improved the system's efficiency, but it was the combination of the two that generated the most significant change.

9 Current data can be found in the semi-annual reports of Administration of Courts. THE STATE of ISRAEL: THE Judicial AUTHORITY, http:/elyonl.court.gov.il/eng/home/index.html (last visited Jan. 12, 2012).

10 Sultsiano-Keinan, et al., The Burden on Judiciary Systems: A Comparative Analysis of 17 Countries, Haifa University Center for Public Management and Pol. ICY (2007).

11 The reform applied to civil cases at first, including family law cases. A few years later, some of the case management methods were applied to criminal cases. 
Israel introduced ADR to the judiciary system in 1992, following the amendment of the Courts Act of $1984 .^{12}$ In the late 1990s, two commissions were appointed: the Or Commission ${ }^{13}$ and the Gadot Commission. ${ }^{14}$ The Or Commission was appointed to analyze the court system's structure, and the Gadot Commission was appointed to delineate the qualification of court-appointed mediators and their training program. ${ }^{15}$

The recommendations of both commissions set the baseline for the Case Management and ADR Programs. Cooperation between the Supreme Court President, the Honorable Professor Aaron Barak, and Professor Sander led to the first pilot in Tel Aviv Magistrate Court. The pilot was headed by the President and the Honorable Judge Dan Arbel and managed by the Honorable Judge Ilan S. Shilo. The program started as the multi-door courthouse model proposed by Professor Sander, and evolved in response to stakeholder and public feedback to meet the distinctive requirements of the Israeli system.

\section{San Mateo Superior Court: Multi-Option Appropriate Dispute Resolution Project (MAP)}

The Superior Court of San Mateo County's Multi-Option ADR Project (MAP) was based on the premise that the court should try to provide disputants with the most appropriate dispute resolution option for their particular case, whether that be litigation, mediation, or some other dispute resolution process. Mediation is viewed as just one option in the spectrum of dispute resolution processes available to disputants. The program began with a civil mediation program in 1996, prompted in part by delayed trial dates due to the newly implemented "fast track" rules. The stakeholders convened were from the community medi-

12 The amendment contains three options for ADR: Section 79(a) enables the court to propose an abridgement ruling that the disputants cannot later appeal; Section 79(b) enables the court to refer the case to arbitration; and Section $79(\mathrm{c})$ enables the court to refer the case to mediation.

13 Theodor Or, Report of the Commission for Examination of the Regular Courts Structure (Aug. 1998).

14 Sarah Gadot, Report of the Consulting Commission to Court Mediation (May 1998).

15 Based on the Gadot Commission's recommendations, the Courts Regulations of 1996 (mediators panel) were amended in 1999, but cancelled in April 2008. Current Israeli law enables anyone to be a mediator. The Rubinstein Commission (discussed below) set the qualifications for mediators participating in the mandatory mediation program. 
ation program, the bar association board, and the bar association ADR committee, along with judges and the court CEO.

MAP started small, focusing at first on offering mediation in general civil cases through a partnership with the local county bar, the community mediation center, and the Peninsula Conflict Resolution Center. In the civil program, judges can engage disputes in a two-part discussion about ADR options during their initial casemanagement conference. First, the judge can mandate that parties meet with ADR staff to discuss and be educated about ADR options. The second step is either to voluntarily agree to proceed with ADR, or to decline ADR, in which case the parties have a trial date. Although the education about ADR may be mandatory, participation in mediation or another form of ADR is voluntary.

Parties who decide with the judge's or court staff's assistance to participate in mediation or another ADR option can select their neutral privately or by consulting the program's carefully screened list of panelists. In several of the MAP programs (civil, probate, and complex litigation), the parties are responsible for paying the neutral for his or her services except when pro bono or modestmeans assistance is needed. To provide this assistance, the staff screens parties based on income and works with the whole panel to make mediation and other ADR services fully accessible to all who use the court.

Initial success with the civil mediation program enabled the program to grow. Other forms of ADR, such as neutral evaluation, were added to the civil program. Two preexisting court programs-small claims mediation and judicial arbitration-were integrated into the project.

An existing partnership with the local bar and community mediation center enabled the court to include juvenile dependency and a comprehensive family law ADR program. With respect to dependency, the court initially partnered with the community mediation center to hire a part-time coordinator to oversee volunteer mediators. Following the program's success, the court sought and received State trial court funding for a program coordinator position at the court. Now families at all stages of the dependency process have access to free mediation services to help clarify and resolve issues.

With respect to family law, the San Mateo County Bar Association originated a small program that was later brought in-house to the court through State trial court funding. For many years, and up until severe budget cuts beginning in 2008, a staff attorney-media- 
tor was available on site at the court. There was, and still is, a panel of private attorney mediators and arbitrators to whom cases can be referred. Volunteer attorney mediators have been recruited and trained in order to replace the staff attorney mediator for the on-site mediations.

The probate and complex litigation programs share with the main civil program market-rate private panels of neutrals with pro bono neutrals available based on need. The juvenile delinquency program employs restorative justice techniques to bring together juveniles and the persons victimized by their behavior. Volunteers trained by the community mediation center provide the mediation services, which are free to the parties, and court staff manages the program.

\section{Analytic Framework for System Design}

The analytic framework proposed by Stephanie Smith and Janet Martinez ${ }^{16}$ is summarized below and then used to assess the experience of the Delhi Mediation Center in the Delhi district courts, the Israel Judicial Court in Tel Aviv, and the San Mateo Superior Court in California.

\section{THE ANALYTIC FRAMEWORK}

1. Goals

a) What does the system's decision-maker(s) seek to accomplish?

b) Which types of conflicts does the system seek to address?

2. Stakeholders

a) Who are the stakeholders?

b) What is their relative power?

c) How are their interests represented in the system?

3. Processes and Structure

a) Which processes are used to prevent, manage, and resolve disputes?

b) If there is more than one process, are processes linked or integrated?

c) What are the incentives and disincentives for using the system?

d) What is the system's interaction with the formal legal system?

4. Resources

a) What financial resources support the system?

b) What human resources support the system?

5. Success and Accountability

a) How transparent is the system?

b) Does the system include monitoring and evaluation?

c) Is the system successful?

16 Lisa Bingham, Janet Martinez \& Stephanie Smmt, Dispute System Design: Preventing, Managing and Resolving Conflict (forthcoming, 2013); Stephanie Smith \& Janet Martinez, Analytic Framework for Dispute System Design, 14 HARv. Negor. L. Rev. 123 (2009). 


\section{A. Goals}

The first element of the framework, the goals, seeks to identify the types of conflicts the system seeks to address, and to determine the system's objectives. Prioritizing the desired outcomes helps clarify the policy direction ex ante and assess the system's success ex post.

A court's essential function is to determine, according to the facts and the law, the rights of the parties coming before it. While time and cost savings for the court are often front and center, many courts have realized that a powerful parallel reason for implementing such a program is to improve the public's trust in, and satisfaction with, the courts. Parties can gain a sense of procedural justice through employing various forms of ADR, notably that of mediation: their voices can be empowered, and they can enjoy fair treatment, reduced hostility and costs, expedited resolution, and increased overall satisfaction.

The trade-offs inherent in competing goals may affect the quality of the resulting system. Significant tension can arise among the goals of efficiency, fairness, and justice. For example, what goal is achieved if a court sanctions certain behaviors while punishing others? Is the primary aim to deter parties from future disputes? Can court services realistically guarantee satisfaction to all? Can court outcomes provide long-term durability of resolutions, or merely more short-term results? One might argue that these unavoidable conflicts might affect fairness in some cases but enhance efficiency in others.

Indian disputes referred to mediation include business and commercial, insurance, matrimonial (divorce, custody, and dowry), intellectual property, labor and management, property, and tort recovery. Clearly, the driving objective of mediation referrals has been to reduce the case backlog by offering a less time-intensive and less expensive process to resolve a wide range of disputes.

The objectives of the Israeli program have been to adopt ADR process options and case-management policies in order to provide optimal service within the limits of its resources. The focus has been on reducing case-processing time and lessening the volume of cases for the judges. Furthermore, the program aimed to introduce ADR to and encourage its use by the public.

As noted above, in San Mateo Superior Court, cases in family, probate, civil, complex litigation, juvenile, and small claims each 
- To what degree the court should encourage or require use of an ADR option.

- Whether certain cases should be exempt from specific (or all) ADR options.

In the Indian programs, mediation may be recommended at any stage, but preferably after admission/denial. The referring judges assess cases for mediation based on party characteristics, case characteristics, legal issues, and the number of parties.

In a bid to deal with case overload and provide respite outside court, the Chief Minister of the Delhi Cabinet, Sheila Diskhit, together with the Delhi High Court and the author, in his capacity as Principal Secretary, formed the Delhi Disputes Resolution Society. Under its auspices, eight mediation centers have been established throughout Delhi. The mission of these community mediation centers is not only to reduce the debts of pending cases, but also to target the cases at a pre-litigation stage and to promote social harmony. Types of cases served include those relating to family disputes (domestic violence, maintenance, custody, separation), consumers, community disputes, commercial practice, schools, check bouncing, administrative tribunals, police complaints, and personal injury and accident compensation. The government plans to seek the services of retired judges and reputed advocates. Furthermore, the information technology department is working to establish software to avoid unnecessary paperwork and delays.

The Israeli structure focuses on both ADR and case management. The first step in its structural overhaul was the establishment of a new legal division in 1997, the Case Management and ADR Department. The new departments' responsibilities included implementing case-management methods, referring and monitoring cases referred to ADR, and providing legal assistance to the judges. The new elements of case management included constructing specialized departments, such as the department for torts. ${ }^{18}$ Classification and preparation were accomplished mostly by evaluating cases prior to pre-trial hearings. ${ }^{19}$ Providing judges with the relevant information and documentation of their respective cases by the first hearing had a significant impact on judicial time.

\footnotetext{
18 The departments include the department for torts, the department for contractual claims and supply of goods, the department of banking loans and credit, the department for property, the department for libel, intellectual property, and complex commercial cases.

19 The directions have been given in accordance with the judge's guidance and based on the specific case. It enabled tailoring different case management procedures for each case as required.
} 
The criteria for referring cases to mediation in the Israeli program were eliminative. The court's directions were not binding, and it did not take any position on parties' response. Cases were referred to mediation at every stage of the trial. The obvious advantages of $A D R$ to the court and the public included time saved, a reduction in overall costs, and improvement of parties' relationships. The state also incentivized ADR by providing a full refund of court fees to those who used it to resolve their cases. ${ }^{20}$ The disputants choose between internal or external mediation. ${ }^{21}$

In San Mateo, disputants are informed of ADR options upon filing, whether they are in the civil, probate, complex litigation, small claims, juvenile, or family departments. Professional and highly skilled neutrals are provided by different methods and at different times in each program area. For example, in civil, probate, and complex matters, parties are given prescreened lists of market-rate neutrals (mediators, arbitrators and neutral evaluators), or they can select a neutral on their own. They are given a time frame in which to submit a stipulation providing the court with the neutral's name and the ADR session's date. They split the costs unless pro bono is requested and granted.

In the small claims and two juvenile programs, mediations are provided free of charge by trained community volunteers overseen by court staff. In the family law ADR program, there are free staff volunteer mediators on site for short-cause matters, and a private panel of trained family law mediators and arbitrators who handle the first ninety minutes on a reduced-fee basis. Key factors that have contributed to the growth and development of the program include:

- Broad participation in the development and implementation of the program, from the judges, local bar, community mediation center, and other community partners.

- The use of professional ADR staff helps keep the program on track. For example, the program director's expertise and ability to engage a wide range of people (judges, attorneys, and disputants) have been critically important in securing the support needed for all aspects of the program.

- Appropriate referral of disputants to an ADR option that meets their needs. Otherwise, parties are likely to be dissatisfied with the program or the court.

20 The disputants are referred to the Administration of Courts website for information about the different ADR options, and to the list of neutral parties involved.

21 Internal mediation took place at the courthouse and was facilitated by court attorneys. Mediators approved by the Administration of Courts facilitated external mediation. 
- High-quality neutrals and the ability to track success. Each of the programs provides evaluations to all participants, attorneys, and neutrals for all cases.

\section{Stakeholders}

The third element influencing ADR implementation in different countries is the identification of stakeholders and their relative power. Stakeholders include the immediate parties in conflict, their counsel, the court itself, the court's employees, and the citizens within the jurisdiction. In examining the various stakeholders involved, one must ask how the introduction of a new system allows for the different stakeholder interests to be met.

Many lawyers of various Delhi bar associations were not interested in adopting alternative dispute resolution practices, so the MCPC started the program with officers of the Delhi Higher Judicial Services. The Delhi High Court approved draft rules on mediation for the Delhi jurisdiction. After initial resentment, lawyers gradually began participating.

The reform of the Israeli court system and the implementation of ADR were initiated by the Israeli judicial system. The president of the Supreme Court, the Honorable Judge Aaron Barak, supported and encouraged the use of ADR. Judge Barak's view was that, ideally, the courts would deal with disputes that had to be resolved through judicial rulings, while the remainder-indeed, the large majority - of the cases would be dealt with by means of alternative methods, such as arbitration and mediation. ${ }^{22}$ Judge Barak emphasized that "the importance of mediation is in off-loading the backlog of the courts; it is not its goal, but it should be its result." 23

The Israeli Bar Association's approach was disjointed. Some voices strongly opposed any kind of change to case-management practices, while others supported the process and called for attorneys to get training as mediators and take an active role in the reform. From the stakeholders' perspective, the neutrals represented the court and had to meet the highest standards of professionalism.

Initially in Tel Aviv, there were no limitations placed on the number of people who could qualify for the external mediators'

22 Aaron Barak, About Mediation, 1 SHA'AREi MishPat 9 (2002), http:/www.mishpat.ac.il/ files/650/3118/3124/3125,pdf.

23 Id. at 10. 
panel, and the list kept growing rapidly, ultimately including thousands of mediators. As a result, there were too many mediators who were fully trained but lacking practical experience. ${ }^{24}$ This situation led to growing dissatisfaction among attorneys and disputants with the level of mediator professionalism. As a result, willingness to participate in mediation decreased in some courts. In response to this declining interest in mediation, the Rubinstein Commission ${ }^{25}$ established a pilot program of mandatory mediation. The program was launched by three Israeli courts in September 2008. According to the program, disputants in cases exceeding 50,000 NIS had to attend a pre-trial meeting called a "mahüt," an acronym for "familiarity and coordination gathering." The major change is that the mahüt is facilitated by an external mediator chosen from a panel of mediators who have been rigorously examined. In the mahüt meeting, the disputants present their respective complaints and hear from the mediator about the various options available for resolving the case. It is then each disputant's choice as to whether to proceed with mediation or go to trial.

In San Mateo, minimum mediator qualifications for the civil, probate, and complex programs include a combination of training of at least forty hours and experience in at least five mediations, or other substantially equivalent background. References are requested of applicant neutrals and observation may be requested. Stakeholders included bar association and community mediation program members and other relevant agency and community group representatives who served alongside judicial officers on advisory committees formed for each new program. For example, the juvenile mediation program advisory committee consisted of not only probation, district attorney, and social worker representatives, but also mental health professionals from referring schools and juvenile liaisons from some of the local police departments, along with the ADR staff and juvenile judges.

\section{Resources}

There are vital concerns regarding the extent to which the judicial system can provide adequate resources for the incorporation

24 A hidden benefit was that many of the mediators not mediating court cases developed and implemented mediation programs in communities and schools instead.

25 Michal Rubinstein, Report of the Committee to Assess Ways to Increase the Use of Mediation to Decrease the Burden on the Judiciary System (2006). 
of ADR. How will the system be financed, and is its funding level adequate to achieve the stated goals? What impact do the amounts and sources of funding appear to have on the results of the system? On the human resource side, are neutrals adequately trained to provide quality and ethical services? Do other personnel in the system (internal and external to the organization) have sufficient skills, training, and supervision? A system can achieve its goals only if it is adequately supported. To avoid creating an elaborate set of processes with inadequate resources, stakeholders may be required to make hard decisions that, as noted above, may have an impact on fairness, justice, and the likelihood of success.

Limitations influence different approaches to creating an ADR operation. Two major staffing models are used in court ADR programs. Courts with a "staff-neutral" model employ specially trained court staff to serve as the ADR neutrals. This model is used in a number of Federal Circuit Courts of Appeal and a smaller number of district courts in the United States. The model was used in the Israeli program.

Largely due to cost considerations, however, many courts use a panel model, relying on private practitioners to serve as ADR neutrals on a court-administered or court-sponsored panel. ${ }^{26}$ In the Indian program, judges and attorneys with ten years of practice and forty hours of training may be mediators. The cost is free for disputants and their court fees are refunded. The government pays lawyer mediators. The DMC, under the MCPC, conducts various training programs for judges and lawyers in Delhi and in the different states of India, including training aimed at increasing the awareness of mediation, highlighting the role of the referring judges and lawyers, and providing refresher courses for mediators with subject-specific training and more.

It is important to note that in Israel there are higher attendance and resolution rates in cases using internal mediation than in those that are referred out, with an attendance study revealing internal mediation attendance rates at eighty percent versus the external mediation rate of fifty percent.

Some external mediators have argued that having the option of internal mediation was the reason for the decrease in external mediation participation. Another argument was that internal

26 The rough division of court ADR delivery options into these two categories oversimplifies the terrain. For a more detailed discussion of five different models and their strengths and weaknesses, see Wayne D. Brazil, Comparing Structures for the Delivery of ADR Services by Courts: Critical Values and Concerns, 14 OHIO ST. J. ON Disp. Resol. 715 (1999). 
mediators used a more evaluative mediation style and that therefore the rate of resolution was higher. The higher attendance and resolution rates through internal mediation might be connected to internal mediation's sponsorship by the courts, which perhaps increased public confidence in the process. Furthermore, internal mediators had an opportunity to handle a higher volume of cases and thus deepen their experience. ${ }^{27}$

In every dispute system design, the most important resource is human talent. All models rely on the generosity of the mediators, many of whom volunteer their preparation time and first ninety minutes or more. In order to continue to uphold the public mandate of providing such accessible and affordable services, judiciaries must find ways to increase their funding, and the state and the judiciary must keep and attract skilled mediators.

\section{E. Success and Accountability}

The last element to assess is the success of the ADR program in each setting. On the ground level, one must ask to whom is the system accountable? Is the system transparent in terms of its operation, access to processes, and result? Does the system include an evaluative component, and, if so, what is studied, when, by whom, and for whom? Finally, is the system successful when measured against its goals and other relevant legal and societal norms?

A system's success is best judged if outcomes are made available to, and studied by, independent evaluators. Unfortunately, barriers such as cost, privacy concerns, and difficulty often preclude independent evaluation from taking place. At a minimum, evaluation should begin with internal monitoring, including some combination of data collection on usage, surveys, and focus groups designed to obtain candid feedback from key stakeholders. Of course, independent external review is preferable and can provide a more detailed and objective assessment.

In India, the DMC issues newsletters and annual reports. As of December 2012, the DMC had settled over 70,000 cases, with an average success rate of seventy percent. ${ }^{28}$ The DMC pilot has led

27 Whether or not internal mediation is necessary to establish an ADR system is a complicated question. See Wayne D. Brazil, Should Court-Sponsored ADR Survive?, 21 OH1O ST. J. ON DisP. RESOL. 241 (2006).

28 Delhi Mediation Centre: District Courts of Delhi, http://delhimediationcentre.gov .in/nl2012.htm (last visited Mar. 16, 2013). 
to a national plan on mediation to encourage use of mediation as a speedy, inexpensive, and high-quality alternative to litigation.

The success of the Case Management and ADR program in Tel Aviv was measured by the goals defined at the outset. By September 2000 , just two years after the program's initiation, the average time it took to process and complete a civil case had been reduced from five years to two. The other goal, namely that of reducing case volume, had also been achieved. ${ }^{29}$

The evolution and success of the Israeli Case Management and ADR program was partly based on periodical re-examination of the program's performance. Monthly, semi-annual, and annual reports monitored the program's effectiveness. The relentless search for new methods to enhance judicial efficiency resulted in tangible success.

Recent data assessing the progress of the mandatory mediation program (mahüt) can be found in the Rubinstein Committee's intermediate report, which analyzed 1,213 pilot cases referred from three different courts (Jerusalem, Tel-Aviv, and Rishon Lezion). The research methods for the report included both qualitative and quantitative approaches. The report indicated that most of the disputants and their attorneys were highly satisfied with the mediator's professionalism. During the pilot period of September 2008 to March 2009, $52.9 \%$ of the disputants chose mediation to resolve their conflicts. Most of the attorneys and disputants participating in mediation were satisfied with the process, and $61.4 \%$ resolved the conflict through mediation. Sixty-five percent of the disputants said they would recommend mediation to family or friends.

In San Mateo, the Civil and Probate ADR Program is a voluntary, market-rate program, with income-based, pro bono, and modest-means services available. Referrals are provided by trained and experienced neutrals who are attorneys, non-attorney professional neutrals, and retired judges. These professionals are all asked to respond to evaluations of the programs.

There were 741 cases referred to the Civil ADR Program for the 2007-2008 fiscal year. ${ }^{30}$ For the Civil ADR Program report,

29 See The Administration of Courts Report. The reduction in volume should be credited not only to the case management and ADR reform, but also to appointment of judges and to the 24th amendment of the Execution Act.

30 The following statistics on the San Mateo ADR program come from SuPERIOR COURT OF California, County of San Mateo, Multi-Option adr Prouect Evaluation Report, JULY 2007 - JULY 2008 (2009), http://www.sanmateocourt.org/documents/adr/2007_2008_evalua tion_report.pdf. 
only one quarter of the year's data was captured, from October 2007 to December 2007. In this quarter, of 170 cases referred to the program, ninety-six responded to the survey. ${ }^{31}$ With respect to voluntary participation, seventy-three percent of cases referred to the program proceeded to ADR, and twenty-seven percent did not or had not yet gone to ADR. ${ }^{32}$ Of those cases where ADR had been utilized, seventy-one percent settled fully and three percent partially settled. ${ }^{33}$ Twenty-six percent did not settle at an ADR session. ${ }^{34}$

In all cases in which an ADR process was chosen, mediation was utilized. The duration of the average ADR session was 4.0 hours, with an average of 1.2 sessions. The types of cases included personal injury (thirty-six percent), business (twenty-six percent), real estate (thirteen percent), employment (nine percent), construction (five percent), professional malpractice (three percent), complex litigation (three percent), and other/insurance/intellectual property (five percent). ${ }^{35}$ Ninety-five percent of respondents thought that court time was reduced as a result of ADR, while five percent thought court time was increased. ${ }^{36}$ Eighty-five percent of respondents thought that $A D R$ reduced costs, while fifteen percent thought ADR increased costs. ${ }^{37}$ Forty-nine percent of plaintiffs' attorneys and twenty-eight percent of defense attorneys who responded to the evaluation thought that proceeding with ADR reduced litigation costs in the range of $\$ 10,000$ or less. ${ }^{38}$ Forty-six percent of plaintiffs' attorneys and fifty-six percent of defense attorneys estimated cost savings in the range of $\$ 10,000$ to $\$ 50,000 .{ }^{39}$

With respect to the timing of ADR sessions, forty-two percent were held after some preliminary discovery had been completed, thirty-percent after significant discovery, twenty-two percent when trial was imminent, and six percent within four months of filing. ${ }^{40}$

Below are the results in terms of satisfaction rates, based on responses from plaintiffs, defendants, and counsel:

\footnotetext{
31 Id. at 6.

32 Id. at 7

33 Id. at 9 .

34 Superior Court of California, County of San Mateo, Multi-Option AdR Pro. Ject EVAl.uAtion RePort, July 2007 - July 2008, supra note 30, at 9.

35 Id. at 13.

36 Id. at 16.

37 Id. at 17.

38 Superior Court of California, County of San Mateo, Multi-Option adr Pro. Ject Evaluation Report, July 2007 - July 2008, supra note 30, at 18.

39 Id.

$40 I d$. at 4 .
} 
Fairness of process:

Neutral understood key issues:

Would use the neutral again:

Would use MAP program again:
$78 \%-92 \%$ were satisfied/very satisfied

$80 \%-90 \%$ were satisfied/very satisfied

$80 \%-89 \%$

$80 \%-90 \%$

Summary TABLE

\begin{tabular}{|c|c|c|c|}
\hline & Delhi, India & Tel Aviv, Israel & San Mateo, California, USA \\
\hline Goals & $\begin{array}{l}\text { Decrease caseload; } \\
\text { centralize direction \& } \\
\text { support; improve } \\
\text { accessibility; decrease } \\
\text { cost, time; offer self- } \\
\text { determination }\end{array}$ & $\begin{array}{l}\text { Reduce time and } \\
\text { cost; reduce caseload; } \\
\text { implement ADR; } \\
\text { increase public } \\
\text { satisfaction }\end{array}$ & $\begin{array}{l}\text { Increase court capacity to } \\
\text { resolve cases; provide } \\
\text { ADR; promote public } \\
\text { satisfaction; encourage early } \\
\text { case analysis }\end{array}$ \\
\hline Structure & $\begin{array}{l}\text { Court coordinators; } \\
\text { judges; referrals per } \\
\text { party, case, legal } \\
\text { profile; public } \\
\text { education; DDRC } \\
\text { training center }\end{array}$ & $\begin{array}{l}\text { Modified case } \\
\text { management; ADR } \\
\text { provision with } \\
\text { internal, external and } \\
\text { telephone }\end{array}$ & $\begin{array}{l}\text { Judges; Oversight } \\
\text { Committee (bench, bar, } \\
\text { community); Advisory } \\
\text { Committee (stakeholders); } \\
\text { and Staff. ADR programs } \\
\text { for civillprobate; complex } \\
\text { litigation; family law; small } \\
\text { claims; juvenile dependency } \\
\text { and juvenile delinquency. }\end{array}$ \\
\hline Stakeholders & $\begin{array}{l}\text { Government } \\
\text { Court } \\
\text { Judicial staff } \\
\text { Lawyers } \\
\text { Client parties }\end{array}$ & $\begin{array}{l}\text { Court } \\
\text { Judicial staff } \\
\text { Lawyers } \\
\text { Client parties }\end{array}$ & $\begin{array}{l}\text { Court } \\
\text { Judicial staff } \\
\text { Lawyers } \\
\text { Client parties } \\
\text { Community mediation } \\
\text { centers }\end{array}$ \\
\hline Resources & $\begin{array}{l}\text { State funded; DDRS } \\
\text { as center of ADR } \\
\text { excellence; training; } \\
\text { certification; judges \& } \\
\text { lawyers trained; paid } \\
\text { by court; mediation } \\
\text { service free }\end{array}$ & $\begin{array}{l}\text { Significant human } \\
\text { and political support; } \\
\text { moderate financial } \\
\text { aid }\end{array}$ & $\begin{array}{l}\text { Significant human and } \\
\text { financial resources; need- } \\
\text { based fee waivers, } \\
\text { otherwise market rate } \\
\text { except in small claims and } \\
\text { juvenile (which is free) }\end{array}$ \\
\hline Success & $\begin{array}{l}>70,000 \text { cases settled } \\
(70 \%) \text {. } \\
\text { Faster, cheaper, } \\
\text { reduced backlog. } \\
\text { No independent } \\
\text { evaluation. }\end{array}$ & $\begin{array}{l}\text { Significant reduction } \\
\text { in case time line; } 49 \% \\
\text { (external) to } 91 \% \\
\text { (internal) cases } \\
\text { settled. }\end{array}$ & $\begin{array}{l}\text { Indicators: } \\
\% \text { cases resolved; cost; } \\
\text { time; party satisfaction }\end{array}$ \\
\hline
\end{tabular}

\section{Conclusion}

A confluence of several factors, including easier access to information, the evolution of law, and increases in the size of judiciaries in some regions, has resulted in more litigation and larger caseloads worldwide. Meeting the growing demand has resulted in the evolution and growth of court ADR programs.

The analytic framework examined here exhibited a preliminary comparison of three different court-operated ADR programs 
at three different stages of development and in three different states/nations: India, Israel, and California. Although all three programs shared the same overriding goals of enhancing efficiency, reducing costs, and garnering public trust, the procedures and structures of each program diverged. While India focused mainly on mediation, Israel implemented new case-management methods and a broader ADR program. San Mateo, the locale of the most mature program, developed the most advanced and tailored applications in dispute resolution.

Key factors that contributed to the growth and development of the ADR programs in India, Israel, and California include:

- Starting with a pilot program and slowly expanding to highdemand areas based on the performance of the pilots;

- Educating the public about ADR and providing financial incentives, such as free mediation for low-income parties or waiving court costs if ADR is selected;

- Hiring ADR professionals to staff programs. The expertise of the program director and her ability to network with a wide range of people (judges, attorneys, disputants) were critically important to securing the support needed for all aspects of the programs;

- Engaging the stakeholders-including judges, local bar and community mediation center members, and other community partners-in the development and implementation of the respective programs;

- Keeping consistent players, such as insurance corporations, banks, and government entities, apprised of the reforms, and attaining their feedback;

- Ensuring quality control in the selection of and training of mediators; and

- Performing ongoing analysis of success through annual reports, surveys, and feedback from stakeholders.

\section{Future Trends}

The role of technology in the field of ADR may affect the court-annexed programs in the future. In March 2003, new court system software was introduced in the Israeli courts. The software coordinates all relevant information: trial dates, motions and decisions, the judges' calendars, and more. The system enables followup on documents required by the parties. Failure to submit such documents on time may result in rescheduling the hearing in order 
to prevent wasted judicial time. The software further enables decisions and messages from the court to be sent to the parties via email/fax, right after they have been given in court. These functions have significantly improved lawyers' efficiency through online access to information. Because the software enables electronic filing for certain matters, the number of cases filed electronically is growing exponentially every year. ${ }^{41}$

It appears that the Israeli legal culture will continue its movement toward early case handling. ${ }^{42}$ ADR is well on its way to becoming rooted in the Israeli system. The positive trend that the Rubinstein Pilot established will necessarily affect public perception, encouraging attorneys and disputants to approach mediation prior to court proceedings, and may ultimately reduce further the volume of court cases.

The challenges for the future relate to the implementation of additional methods of dispute resolution, early evaluation by neutral parties, and non-binding arbitration. ${ }^{43}$ The recent amendment of the Arbitration Act, which enables consented appeal, may encourage more disputants to use that method. ${ }^{44}$ It is of paramount importance to keep the new generation of attorneys abreast of the innovative methods available for conflict resolution. In an age in which information is easily accessible, attorneys will have to meet their clients' needs and provide clients with customized processes to help resolve conflicts.

San Mateo's MAP program has endured and continues to face significant budget and staffing cuts, like many other public agencies in California. Furthermore, the program is expanding responsibility for managing probate investigations, self-help, and Family Court Services custody mediators. MAP's management is trying to use this period to refocus on essential services and adopt an aggressive use of technology. One long-term goal is to assess these added areas for greater use of interest-based dispute resolution. Amidst staffing cuts and increased service responsibilities, MAP's manage-

41 Over the last several years, the Administration of Courts implemented advanced software that transformed the Israeli judicial system into a system based on virtual files. Many of the processes described above are generated automatically in the new system. The system has yet to be implemented in Tel Aviv.

42 For a comprehensive discussion of the movement, see John Lande, The Movement Toward Early Case Handling in Courts and Private Dispute Resolution, 24 OHo ST. J. on Disp. Resol. 81 (2008).

43 See Ruth Ronen, Report of The Committee to Assess Ways to EnHance Efficient Legal Proceedings (June 2008).

44 See Ronen Setty, Appealing Course in Arbitration, Road Test. 
ment is trying to be more open to rethinking how business is done and considering various forms of ADR.

The development of online dispute resolution options-including both facilitative and evaluative processes-may fulfill a need caused by drastic budget cuts in court programs. Technological development is underway for courts in Canada and California. ${ }^{45}$

The experiences of the Indian, Israeli, and California state courts' ADR systems, compared within the analytic framework for dispute system design, may provide insights into the creation of new systems or the improvement of existing ones. Cultural differences have definitely influenced some of the methods described here. Therefore, certain modalities should be tested before being applied outside the system in which they originated. However, the use of the same framework to analyze the systems facilitates the sharing of experiences. The lessons learned from the process involved in the creation and maintenance of the systems will hopefully facilitate the development of ADR systems elsewhere.

45 Recent developments in technologically-enabled access to justice suggest how these options could enhance both party satisfaction and system efficiency. See, e.g., Michael J. Wolf, Collaborative Technology Improves Access to Justice, 15 N.Y.U. J. LeGrs. \& PUB. POL'Y 759, 774 (2012) (on British Columbia's partnering with Modria, a tech start-up developing online dispute resolution systems); Ayelet Sela, Presentation at Hebrew University, Can A Computer Be Fair? Disputants' Experience of Procedural Justice in Automated and Facilitated Online Dispute Resolution (on file with authors). 
